\author{
Maja Kelić \\ Mirta Zelenika Zeba \\ Jelena Kuvač Kraljević \\ Sveuciliste u Zagrebu, Edukacijsko-rebabilitacijski \\ fakultet, Odsjek ra logopediju
}

\section{Što mjerimo pseudoriječima i kako mjerimo pseudoriječi}

\author{
Pseudowords: How are they measured and \\ what should they be used for
}

\begin{abstract}
SAŽETAK
Ponavljanje pseudoriječi jedna je od najčešćih mjera fonološkog radnog pamćenja. Unatoč učestaloj uporabi, nerijetko se pri izradi pseudoriječi malo pažnje posvećuje parametrima koji ih određuju, a pri uporabi zadatka ponavljanja pseudoriječi ne preispituje se uloga ostalih procesa i mehanizama fonološke obrade koji ga podupiru. U skladu s tim, načinjena je lista pseudoriječi varirajući duljinu (broj slogova) i fonološku složenost (strukturu sloga, tj. pristup i odstup sloga). Cilj je ovoga rada utvrditi povezanost ponavljanja pseudoriječi s drugim mjerama radnoga pamćenja - pamćenjem brojeva i slogova. Lista pseudoriječi primijenjena je kao mjera radnoga pamćenja na uzorku djece s posebnim jezičnim teškoćama (N=10, KD: 10;06). Uz ponavljanje pseudoriječi radno je pamćenje mjereno ponavljanjem slogova te ponavljanjem brojeva (WISC-IV). Rezultati pokazuju značajnu i pozitivnu korelaciju između ponavljanja brojeva i slogova, no ponavljanje pseudoriječi nije povezano ni s jednom drugom mjerom radnoga pamćenja. Čini se da ponavljanje pseudoriječi oblikovanih na taj način ne odražava samo opseg radnoga pamćenja, već i intaktnost fonološkog sustava.
\end{abstract}

\begin{abstract}
Repetition of pseudowords is one of the most common measures of phonological working memory. Although pseudowords are widely used, little attention has been given to the parameters that should be taken into account in their construction. Accordingly, a list of pseudowords has been produced by manipulating the length (number of syllables) and phonological complexity (syllable structure, i.e. onset and coda) of each pseudoword. The aim of this research was to determine the correlation between pseudoword repetition and other working memory measures - digit span and syllable repetition. The list of pseudowords, as a measure of working memory, was administered with a sample of children with specific language impairment $(\mathrm{N}=10$, mean age $=10,6$ years). In addition to pseudoword repetition, working memory was measured using syllable repetition and digit span (WISC-IV) tasks. The results demonstrated a significant and positive correlation between digit span and syllable repetition, while pseudoword repetition was not correlated to any other working memory measure. Based on these findings, it seems that pseudoword repetition is not only a working memory measure, but rather reflects the development of the phonological system.
\end{abstract}

Ključne riječi: fonološka obrada fonološko radno pamćenje pseudoriječi

Keywords: phonological processing phonological working memory pseudowords 


\section{UVOD}

Pseudoriječi su nizovi fonema koji poštuju fonotaktička ograničenja nekog jezika, što omogućava njihovo izgovaranje i naglašavanje u skladu s pravilima, a pritom nemaju značenje. Osim fonološki, pseudoriječi odgovaraju jeziku i morfološki, što znači da pseudoriječi u hrvatskome sadrže gramatičke morfeme koji određuju pravila prema kojima će se sklanjati ili sprezati. Napisane pseudoriječi poštuju ortografska pravila jezika pa pseudoriječ u hrvatskome može sadržavati karakteristične skupine kao što su $t s$ ili $d s$, koje se u izgovaranju slijevaju u [c] i čine iznimku od inače vrlo dosljedne hrvatske ortografije. Dakle, jedina razlika između pseudoriječi i riječi jest njihova leksička ovjerenost: riječi imaju značenje, dok ga pseudoriječi nemaju. Pseudoriječi su vrlo korisno oruđe u psiholigvističkim istraživanjima $-\mathrm{i}$ kad su u središtu zanimanja istraživača, primjerice $u$ istraživanjima infleksijske morfologije ili u istraživanjima čitanja, i kad su pomoćno sredstvo za izvođenje nekog zadatka, kao u zadacima leksičke odluke.

Ponavljanje pseudoriječi smatra se mjerom radnoga pamćenja $i$ vrlo se često pojavljuje $i \mathrm{u}$ dijagnostičkim instrumentima upravo s ciljem ispitivanja ove sposobnosti. Unatoč učestaloj uporabi pseudoriječi, nerijetko se malo pažnje posvećuje parametrima koji ih određuju, a u zadatku ponavljanja pseudoriječi ne preispituje se uloga ostalih procesa i mehanizama fonološke obrade koji ga podupiru. Stoga je cilj ovoga rada utvrditi povezanost ponavljanja pseudoriječi s drugim mjerama radnoga pamćenja pamćenjem brojeva i slogova.

\section{Uporaba pseudoriječi}

Neovisno o tome promatra li se jezična obrada kao serijalni (npr. Friederici, 2002) ili paralelni proces (npr. Hagoort, 2005), jezične su razine čvrsto isprepletene i vrlo teško odvojive. Svaka se jezična sastavnica promatra u svjetlu više razine obrade. Primjerice, utjecaj fonološke obrade vidljiv je tek kao odraz fonološkog prilagođavanja tijekom morfološkog označavanja (npr. u riječi vrapci) ili na leksičkoj razini kao rezultat razlikovanja dviju riječi (npr. kozalkosa). Na putu do značenja potrebno je integrirati više razina jezične obrade (npr. u izrazu nema kosa upravljanje omogućuje priziv točne riječi iz mentalnoga leksikona: kos, a ne kosa; zajedno s odgovarajućim segmentalnim i suprasegmentalnim fonološkim obilježjima: kôs - kósâ).

U logopedskom istraživačkom i kliničkom radu bitno je odvojiti pojedine razine obrade, odnosno pojedine sastavnice, kako bi se što točnije odredilo teškoću ili razinu ovladanosti nekom jezičnom sposobnošću. Upravo je to učinila Jean Berko, koja je u svom radu o usvajanju morfologije uvela novotvorenice bez značenja te opisala kako djeca poopćavaju infleksijska pravila, označavaju riječi koje zasigurno nisu dio mentalnoga leksikona i proizvode potpuno nove oblike (Berko, 1958). Time je mogla promotriti usvojenost morfoloških pravila, neovisno o već usvojenim leksičkim oblicima. Mnoga su kasnija istraživanja slijedila ovaj primjer (v. Chialant i Caramazza, 1995; McDonald, 1997). S početkom psiholingvističih istraživanja u Hrvatskoj, oblikovane su i prve liste pseudoriječi upravo s ciljem provjere usvojenosti morfologije (Ljubešić, 1997), a rabljene su i kao podražaj u nizu istraživanja (npr. Palmović i sur., 2007; Zaretsky i sur., 2009; Ivšac Pavliša, Lenček, 2011; Bilonić Milošević, 2012) te u kliničkom radu. Drugo veliko područje u kojem se upotrebljavaju pseudoriječi - i u istraživanju i kliničkoj procjeni - područja su ovladavanja čitanjem te poremećaja čitanja. Prema modelu dvostrukoga puta (engl. dual-route model of reading, Coltheart, 2005, 2006), koji je jedan od najutjecajnijih modela čitanja, da bi čitatelj došao do značenja, potrebna je podrška triju sastavnica mentalnoga leksikona: ortografskog leksikona, u kojem su ortografske predodžbe riječi (vizualne predodžbe koje odgovaraju nizovima grafema); fonološkog leksikona, u kojem su fonološke predodžbe (zvučne predodžbe koje odgovaraju nizovima fonema); semantičkog leksikona, u kojem su uskladištena značenja riječi i koji predstavlja čitateljev krajnji cilj jer dovodi do razumijevanja. Kako je poznate riječi moguće čitati ulazom u ortografski, zatim u semantički leksikon, provjera cjelokupne vještine čitanja uključuje i pseudoriječi koje je moguće čitati samo primjenjujući pravila o povezivanju fonema i grafema, tj. obradom na subleksičkoj fonološkoj razini. Općenito govoreći, ako subleksički procesi nisu razvijeni, čitatelj nije u mogućnosti dekodirati nepoznate nizove grafema pa ih posljedično niti ne može povezati s fonološkom predodžbom i značenjem. Stoga većina instrumenata za procjenu čitanja uključuje i zadatke koji procjenjuju brzinu i točnost čitanja pseudoriječi.

\section{Pseudoriječi kao mjera radnoga pamćenja}

Po definiciji, pseudoriječi omogućuju odvajanje fonološke obrade od ostalih razina jezične obrade, a razlog za to nameću dva najčešća razvojna jezična poremećaja. Iako se posebne jezične teškoće najvećim dijelom očituju u poteškoćama na morfosintaktičkoj razini, dok disleksija podrazumijeva poremećaj u ovladavanju čitanjem, velik broj istraživanja pokazuje da je uzrok teškoća u oba poremećaja upravo na razini fonološke jezične obrade (Chiat, 2001; Bishop, Snowling 2004; Ramus i sur, 2013). Zadatak ponavljanja pseudoriječi pokazao se vrlo korisnim u procjeni jezičnih sposobnosti zbog svoje visoke povezanosti s nizom drugih jezičnih mjera (primjerice, s rječnikom, čitanjem, razumijevanjem, te sintaktičkom složenosti), i to kod populacije urednog jezičnog razvoja (Adams, Gathercole, 2000), ali i kod govornika s jezičnim teškoćama (ContiRamsden, Botting, Faragher, 2001). Mnoga istraživanja izdvajaju ponavljanje pseudoriječi kao vrlo pouzdan pokazatelj jezičnih teškoća, što ga svrstava u skupinu mogućeg kliničkog markera (pregled u Chiat, Roy, 2007). Dollaghan i Campbell (1998) u svom istraživanju pokazuju da pseudoriječi ne samo da dobro izdvajaju govornike s jezičnim teškoćama (s $98 \%$ točnosti), nego je varijabilnost unutar skupina vrlo mala, a između skupine s jezičnim teškoćama i skupine urednog jezičnog razvoja nema preklapanja, što omogućuje uporabu ovog zadatka kao svojevrsne probirne mjere.

Ponavljanje pseudoriječi odražava temeljnu fonološku vještinu, koja je ključna u procesu usvajanja novih riječi. Nakon prepoznavanja i razlikovanja fonema slijedi njihovo 
spajanje te, konačno, prepoznavanje riječi koja je dio govornikova mentalnog leksikona. Kod ponavljanja pseudoriječi ovaj posljednji korak obrade izostaje, pa ta mjera upućuje na sposobnost trenutnog zadržavanja fonoloških predodžbi u radnom pamćenju. Fonološka obrada obuhvaća kodiranje i uskladištavanje najmanjih jezičnih jedinica, tj. fonema i njihovih sljedova, kako bi se njima moglo brzo i točno pristupati, zadržavati ih, obrađivati i njima baratati.

Ponavljanje pseudoriječi često je upotrebljavana mjera radnoga pamćenja, a teškoće u ponavljanju kod djece s jezičnim teškoćama potaknule su na zaključak da je fonološko radno pamćenje jedan od mogućih uzroka posebnih jezičnih teškoća (Adams i Gathercole, 2000). Gathercole i Baddeley (1993) promatraju ponavljanje pseudoriječi kao mjeru fonološkoga radnog pamćenja prikladniju od pamćenja riječi jer njihovo ponavljanje izravnije ovisi o trenutnom zapamćivanju fonološke predodžbe, neovisno o dugoročnom leksičkom znanju koje je može poduprijeti.

\section{Odrednice pseudoriječi}

Ipak, neka istraživanja upućuju na to da ponavljanje pseudoriječi nije jednostavna mjera radnoga pamćenja. U usporedbi s govornicima urednog razvoja, govornici $\mathrm{s}$ jezičnim teškoćama pokazuju veće nedostatke u pamćenju pseudoriječi nego u pamćenju brojeva (Archibald i Gathercole, 2007). Dakle, postignuće u zadacima ponavljanja pseudoriječi nije moguće u potpunosti objasniti radnim pamćenjem. Ti nalazi upućuju na važnost fonološke strukture odabranih pseudoriječi. Osim duljine pseudoriječi, na ponavljanje utječe niz drugih obilježja - fonološka složenost, primjerice slogovna struktura (Kavitskaya i sur., 2011.), artikulacijska zahtjevnost (Nijland i sur., 2002), te prozodijska obilježja (Roy i Chiat, 2004).

Govornici nekog jezika prepoznaju i implicitno upotrebljavaju fonotaktička pravila, odnosno vjerojatnost pojavljivanja pojedinih fonemskih nizova (Gibbs, Van Orden, 1998). Fonotaktička vjerojatnost odraz je posrednog utjecaja leksičkog znanja na ponavljanje pseudoriječi. Gathercole i sur. (1999) pokazali su da je prisjećanje i ponavljanje pseudoriječi s visokom fonotaktičkom vjerojatnošću točnije od pseudoriječi s niskom fonotaktičkom vjerojatnošću. Fonotaktička vjerojatnost utječe na prosudbu o sličnosti neke pseudoriječi s pravim riječima, odnosno mogućnosti da postane dio leksikona (Frisch, Large, Pisoni, 1999). Iako su fonotaktička vjerojatnost i sličnost pseudoriječi s riječima međusobno povezane, mjera sličnosti s pravim riječima - rječolikost (engl. wordlikeness) promatra se i neovisno o fonotaktičkoj vjerojatnosti. Rječolikost podrazumijeva subjektivni dojam o pseudoriječi, odnosno o mogućnosti da navedena pseudoriječ postane riječ u određenom jeziku (npr. govornici hrvatskoga će pseudoriječ plistra na skali rječolikosti ocijeniti bližom riječima nego pseudoriječ trakl). Kada se promatra zadatak ponavljanja pseudoriječi, fonotaktička se vjerojatnost pokazala boljim prediktorom ponavljanja nego rječolikost (Munson, Kurtz, Windsor, 2005).

Pseudoriječi koje sadrže segmente koji su ovjerene riječi, imaju veću mjeru sličnosti s pravim riječima (primjerice, pseudoriječ pamrak koja u sebi sadrži leksičku riječ mrak). No, ovjereni segmenti u konstrukciji pseudoriječi mogu dovesti do efekta redintegracije. Redintegracija podrazumijeva uporabu dugoročnog jezičnog znanja kako bi se popunile praznine, odnosno prizvalo nepotpuni podražaj u zadacima pamćenja ili ponavljanja. To može značiti prizivanje riječi najsličnije ponavljanoj pseudoriječi. Kako bi izbjegli redintegraciju, neki istraživači odabiru slogove koji su fonotaktički mogući, ali su neovjereni, odnosno u jeziku se ne pojavljuju (npr. Stokes i sur. 2006). Sličnost pseudoriječi s ovjerenim riječima moguće je promatrati i u odnosu na neku određenu riječ te je definirati brojeći supstitucije i računajući udaljenost pseudoriječi od riječi, tj. računajući Levensteinovu udaljenost (Greenberg i Jenkins 1964, prema Frisch, Large, Pisoni, 1999). Broj ovjerenih riječi koje čine susjedstvo odabrane pseudoriječi (engl. neighborhood density), također utječe na ponavljanje pseudoriječi (Rispens, Baker, Duinmeijer, 2014).

Zadaci ponavljanja pseudoriječi u istraživanjima jako su različiti, što dovodi i do različitih interpretacija i zaključaka (Coady i Evans, 2008). I zadaci korišteni u istraživanjima, ali i klinički testovi koji uključuju ovaj zadatak, uzimaju u obzir različite odrednice, pa neki ne sadrže konsonantske skupine uopće, dok drugi upotrebljavaju pseudoriječi s neučestalim konsonantskim skupinama, a samo neke mjere uzimaju u obzir rječolikost i artikulacijsku složenost (pregled u Estes i sur., 2007). Razlikuje se i način bodovanja odgovora. Sve navedeno dovodi do velikih razlika između zadataka, a Estes i sur. (2007) svojom metaanalizom pokazuju da zadaci nisu međusobno zamjenjivi $i \mathrm{da}$ razlike u postignućima $u$ ponavljanju pseudoriječi djece $s$ posebnim jezičnim teškoćama ovise o tome koji se zadatak primjenjuje.

Brojni parametri utječu na ponavljanje pseudoriječi te se postavlja pitanje je li zadatak ponavljanja pseudoriječi doista mjera samo radnoga pamćenja. Stoga je cilj ovoga rada provjeriti povezanost ponavljanja pseudoriječi duljine do pet slogova različite fonološke složenosti s drugim mjerama radnoga pamćenja kod djece $s$ posebnim jezičnim teškoćama.

\section{METODE}

\section{Sudionici}

$\mathrm{U}$ istraživanju je sudjelovalo desetero djece s posebnim jezičnim teškoćama prosječne kronološke dobi 10;06 (raspon dobi od 10;02 do 10;11), 6 dječaka i 4 djevojčice. Sudionici su polaznici Osnovne škole Poliklinike SUVAG. Dijagnoza posebnih jezičnih teškoća postavljena im je na osnovi kriterija uključenosti i isključenosti: svi sudionici postižu ispodprosječne rezultate na jezičnim testovima $i$ zadacima, imaju uredne opće kognitivne sposobnosti, uredan sluh te se uvidom u medicinsku dokumentaciju ne nalaze odstupanja u neurološkom razvoju.

\section{Ispitni materijal}

Materijali upotrebljeni u ovom radu oblikovani su u okviru projekta Interdisciplinarni pristup razvoju jezično- 
Tablica 1. Lista oblikovanih pseudoriječi

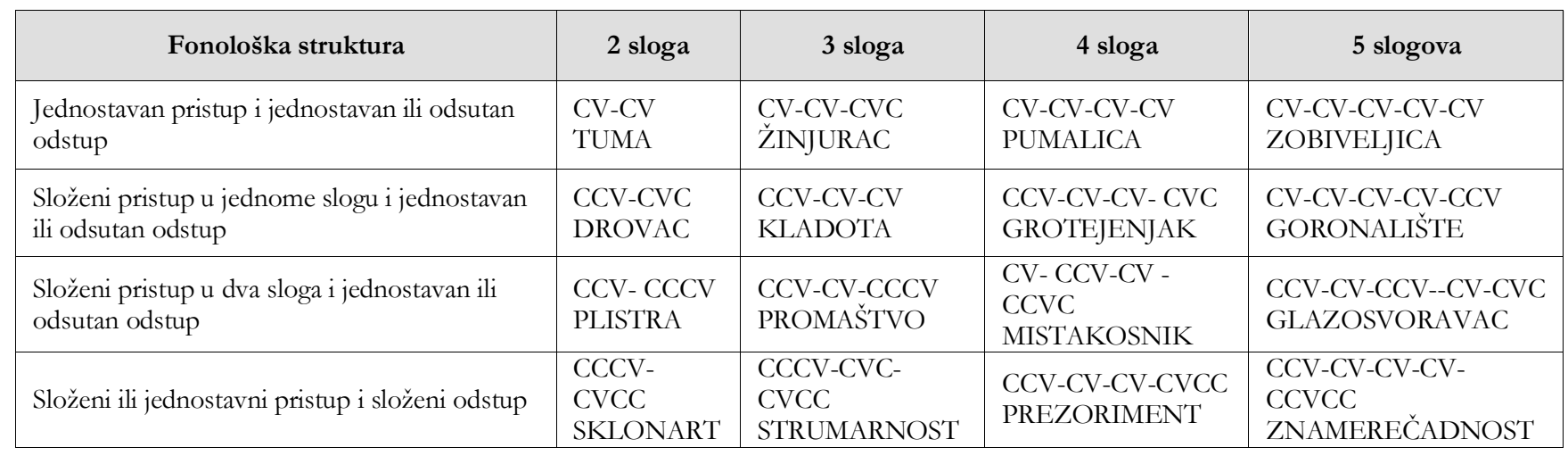

Tablica 2. Lista oblikovanih nizova slogova

\begin{tabular}{|c|c|c|c|c|}
\hline 2 sloga & 3 sloga & 4 sloga & 5 slogova & 6 slogova \\
\hline ti po & ka pi to & be du go ža & me li no ri za & za bo ža ru de ga \\
\hline ge bu & ge ba du & ga bi de za & ča to pi ve šo & pe ti še ko ca ša \\
\hline me ra & me no la & mo ze li ra & lo ze re va mu & lo zi ru ne ve mo \\
\hline ni la & le $\mathrm{mi}$ vo & ša to pi ku & ku pa še ti ca & ži no mu ve la ri \\
\hline pa ko & la ri na & so te ki pa & ga bo ne di za & ba mi za di ge la \\
\hline
\end{tabular}

kognitivnog modela disleksije kod odraslih (HR.3.2.01-0247). Ispitni je materijal uključivao listu pseudoriječi za ponavljanje i zadatak ponavljanja slogova koji su oblikovani za potrebe projekta te zadatak ponavljanja brojeva koji je preuzet iz postojećeg mjernog instrumenta (Wechslerov test inteligencije za djecu, WISC-IV-HR).

\section{Lista psendoriječi za ponavljanje}

Lista pseudoriječi sadrži 16 pseudoriječi različite fonološke složenosti (tablica 1). Pri oblikovanju pseudoriječi mijenjane su dvije odrednice: duljina (broj slogova) i slogovna složenost. Najkraće pseudoriječi su sadržavale dva sloga, a najdulje pet slogova. Svaka skupina riječi prema broju slogova sadrži 4 pseudoriječi. Slogovna složenost je određena složenošću pristupa i odstupa sloga. Prema slogovnoj složenosti oblikovane pseudoriječi se mogu podijeliti u četiri skupine:

- jednostavan pristup i jednostavan ili odsutan odstup,

- složeni pristup u jednome slogu i jednostavan ili odsutan odstup,

- složeni pristup u dva sloga i jednostavan ili odsutan odstup,

- složeni ili jednostavan pristup i složeni odstup.

Pseudoriječi s dva sloga sa složenim odstupom nisu uključene jer su, prema podacima iz korpusa, slogovi sa složenim odstupom vrlo rijetki (KKVKK - 0,13 \%, KVKKK - 0,03\%).

U oblikovanju pseudoriječi upotrijebljeni su slogovi ovjereni u Hrvatskom web korpusu (Ljubešić i Klubička, 2014). Nisu upotrijebljeni slogovi koji samostalno imaju značenje, tj. jednosložne punoznačne riječi (npr. rak, let $\mathrm{i}$ sl.).
Pri odabiru prvog sloga kontrolirana je kohorta riječi koje počinju s odabranim slogom, slogovi s malim kohortama su isključeni (prema Hrvatskom enciklopedijskom rječniku, Anić i sur., 2002). Bigrami na granici sloga su normalno distribuirani (Shapiro-Wilksov test), što znači da je najveći broj prijelaza između jednoga sloga u drugi srednje učestalosti. Time je kontrolirana ovjerenost bigrama u korpusu i učestalost pojavljivanja riječi koje sadrže navedeni bigram.

\section{Ponavljanje slogova}

Kao druga mjera za procjenu funkcionalnosti radnoga pamćenja upotrebljen je zadatak ponavljanja slogova. Zadatak ponavljanja slogova oblikovan je po uzoru na Mottierov test (Mottier, 1951; Wild, Fleck, 2013). To znači da je zadržana forma zadatka, a čestice su izrađene primjenom fonoloških pravila hrvatskoga jezika. Zadatak podrazumijeva ponavljanje izoliranih slogova strukture $\mathrm{KV}$ (tablica 2). Broj slogova koji se ponavljaju je od 2 do 6, u svakoj skupini je 5 čestica (sveukupno 30 čestica). Time se mjeri opseg radnoga pamćenja. U oblikovanju zadatka nastojalo se što manje varirati skupine upotrebljenih konsonanata. Stoga su konsonanti u svakoj čestici ujednačeni po zvučnosti (svi su konsonanti ili zvučni ili bezvučni). U skupini čestica od dva i tri sloga korišteni su sonanti i okluzivi. Unutar jedne čestice upotrijebljena je samo jedna skupina konsonanata (npr. ge ba du). U skupini čestica sa četiri sloga, svaka je čestica sadržavala i jedan frikativ (npr. mo ze li ra), u skupini čestica s pet i šest slogova frikativ i afrikatu (npr. ća to pi ve šo). Vokali su u zadatku distribuirani prema podacima o čestotnosti pojedinog vokala u jeziku (Vuletić, 1991): vokal /a/ 14 \%, vokal /i/ 11 
$\%$, vokal /o/ $10 \%$, vokal /e/ $9 \%$, vokal /u/ $3 \%$. Na osnovi tih podataka napravljena je raspodjela za svaku skupinu čestica prema duljini sloga.

\section{Ponavljanje brojeva}

Kao mjera ponavljanja brojeva upotrijebljen je subtest Raspon pamćenja brojeva iz Wechslerova testa inteligencije za djecu (WISC-IV-HR), kojim se ispituje pamćenje brojeva istim i obrnutim redoslijedom.

\section{Opis ispitivanja}

Za ponavljanje pseudoriječi sudionicima je rečeno da će čuti neke neobične riječi te ih trebaju ponoviti onako kako čuju. Točnima su bodovane samo u potpunosti točno ponovljene pseudoriječi, osim kod jednog sudionika s rotacizmom kod kojeg je kao točno ponovljena bodovana $i$ pseudoriječ u kojoj je glas " $r$ " distorziran, s obzirom na to da se kod navedenog sudionika glas " $r$ " realizira gutiralnom inačicom te se radi o motoričkom, a ne fonološkom poremećaju.

U zadatku ponavljanja slogova ispitivač je čitao slogove ritmom od približno jedne sekunde (približno jednakom brzinom kao brojeve u zadatku ponavljanja brojeva). Sudionici su dobili uputu da ponove slogove koje su čuli i da ih pritom ne spajaju u riječi. Točnima su bodovani oni slogovi koji su ponovljeni s obzirom na foneme i njihovo mjesto u nizu. U vezi s artikulacijskim pogreškama zadržan je isti kriterij kao kod pseudoriječi. Za konačno postignuće uzet je postotak točno ponovljenih slogova.

Za zadatak ponavljanja brojeva preuzeta je uputa prema predlošku u Wechslerovu testu inteligencije za djecu (WISCIV-HR).

Redoslijed rješavanja zadataka za svakog je ispitanika mijenjan, slijedeći pravilo latinskog kvadrata, kako bi se umanjio učinak zamora.

\section{REZULTATI I RASPRAVA}

Osnovni podaci, prosječne vrijednosti i standardni rezultati, za tri promatrane zavisne varijable prikazani su u tablici 3.

Tablica 3. Prosječne vrijednosti i standardne devijacije na promatranim zavisnim varijablama

\begin{tabular}{|l|c|c|}
\hline \multicolumn{1}{|c|}{ Mjere } & M & SD \\
\hline Ponavljanje pseudoriječi & 9,2 & 4,07 \\
\hline Ponavljanje slogova & 63,5 & 12,27 \\
\hline Ponavljanje brojeva (SR) & 5,8 & 2,78 \\
\hline
\end{tabular}

$\mathrm{M}=$ aritmetička sredina; $\mathrm{SD}=$ standardna devijacija

Provedena je analiza povezanosti rezultata na promatranim varijablama: ponavljanju pseudoriječi, slogova i brojeva.
Između ponavljanja slogova i ponavljanja brojeva dobivena je visoka značajna korelacija $(r=0,77, p<0,01)$. No, ponavljanje pseudoriječi nije se pokazalo povezanim ni s jednom od dviju mjera radnoga pamćenja (ponavljanjem slogova i ponavljanjem brojeva). Taj rezultat upućuje na zaključak da ponavljanje pseudoriječi ne ovisi samo o radnome pamćenju, te da na ponavljanje pseudoriječi snažno utječe fonološka struktura oblikovanih pseudoriječi.

$\mathrm{U}$ pseudoriječima upotrijebljenim u ovom ispitivanju mijenjana je ne samo duljina, nego i fonološka složenost, varirajući složenost pristupa i odstupa sloga. Iako radno pamćenje zasigurno podupire ponavljanje pseudoriječi, ponavljanje pseudoriječi oblikovanih na takav način ne odražava samo opseg radnoga pamćenja, već i intaktnost fonološkog sustava. Kod ponavljanja pseudoriječi zvučni je podražaj obrađen na razini subleksičkih fonoloških reprezentacija i takav zadržan u radnome pamćenju. Iako na njegovo zapamćivanje ne utječu izravno leksičko-semantičke predodžbe, podupiru ga fonološka leksička znanja koja uključuju implicitno poznavanje fonotaktičkih ograničenja, odnosno pravila o mogućnosti pojavljivanja pojedinih fonema unutar sloga i njegovih dijelova: pristupa, jezgre $i$ odstupa sloga. Kako su u oblikovanju pseudoriječi za ovo istraživanje upotrijebljeni ovjereni slogovi, kontrolirajući veličinu kohorte prvoga sloga, umanjila se mogućnost redintegracije te je dobiven bolji uvid $u$ razvijenost fonološkog sustava. Naime, slogovi s malim kohortama lako dovode do redintegracije jer je u mentalnom leksikonu manji broj čestica s određenim početnim slogom i veća je vjerojatnost brzog prizivanja leksičke riječi koja počinje određenim slogom. U oblikovanju pseudoriječi metoda primjene slogova prethodno ovjerenih u korpusu primjerenija je od jednostavnog premetanja slogova ili fonema u riječi kako bi se dobila pseudoriječ, što je vrlo čest način oblikovanja pseudoriječi trenutno upotrijebljenih u istraživačke ili kliničke svrhe. Primjerice, premetanjem fonema od riječi lonac dobije se pseudoriječ naloc. No, ovakav pristup ne omogućuje kontrolu učestalosti slogova u jeziku (prema provedenoj analizi korpusa slog „nac“ ima relativno visoku učestalost, a slog „loc“ ima vrlo nisku učestalost, što ga čini neprimjerenim izborom u oblikovanju pseudoriječi). Premetanje slogova lako dovodi i do efekta redintegracije (npr. pseudoriječ plocopak je zbog vrlo karakteristične strukture i ponavljanja grafema fonološki vrlo slična riječi poklopac od koje je nastala).

Iako je ovo istraživanje provedeno na vrlo malom uzorku, rezultati istraživanja upućuju na važnost razmatranja parametara koji određuju pseudoriječi pri njihovom oblikovanju i uporabi - za istraživačke, ili kliničke svrhe. Djeca urednoga jezičnog razvoja pri ponavljanju pseudoriječi primjenjuju ove odrednice kao obrazac koji omogućuje lakše ponavljanje, što pokazuju razmjerno bolji rezultati u ponavljanju pseudoriječi, nego u zadatku ponavljanja izoliranih slogova (Archibald i Gathercole, 2007). S druge strane, upravo uklopljenost slogova u složeniju strukturu djeci s jezičnim teškoćama otežava ponavljanje. Narušen fonološki sustav ne može poduprijeti ponavljanje pseudoriječi. Koartikulacija, prozodijske karakteristike te planiranje složenih konsonantskih skupina dodatno otežavaju ponavljanje pseudoriječi. Dakle, ponavljanje pseudoriječi iznimno je zahtjevan zadatak, a teškoće mogu odražavati nedostatak u bilo kojem dijelu obrade: sposobnost uočavanja razlika u slušnom podražaju, 
preciznost u organizaciji fonoloških, ali i morfoloških predodžbi, pohranjivanje riječi, motoričke i artikulacijske vještine pri ponavljanju (Estes i sur., 2007). Čini se da zadatak ponavljanja slogova u kojem su fonološka obilježja konsonanata u slogu kontrolirana, u odnosu na ponavljanja pseudoriječi, izravnije odražava opseg radnoga pamćenja.

Mišljenja o tome što teškoće ponavljanja pseudoriječi doista govore o razvijenosti jezičnog sustava razlikuju se i različite teorije uzroka posebnih jezičnih teškoća ih donekle različito tumače (npr. nedostaci radnoga pamćenja u Gathercole i Baddeley, 1990; Montgomery, 2002; fonološka osjetljivost u Metsala 1999; općenito smanjeni kapaciteti obrade informacija u Ellis Weismar i sur., 2000). No, ponavljanje pseudoriječi smatra se jednim od najboljih pokazatelja jezičnih teškoća (Chiat i Roy, 2004) te postoje opravdani razlozi za uporabu zadataka ponavljanja pseudoriječi, kao i oblikovanje standardizirane mjere ponavljanja pseudoriječi u hrvatskome koja bi omogućila probir djece s jezičnim teškoćama.

Nekoliko je ograničenja u ovom radu, primjerice nedostatak kontrolne skupine, te je sposobnost ponavljanja pseudoriječi ispitana malim skupom pseudoriječi. Za provjerenije zaključke, ponavljanje pseudoriječi potrebno je ispitati iscrpnijim listama, koje bi uključivale veći broj čestica na kojima bi se mogao ispitati svaki od fonoloških kriterija posebno (npr. utjecaj duljine, tj. broja slogova, slogovne složenosti, prozodijskih karakteristika, rječolikosti i fonotaktičke vjerojatnosti).

\section{LITERATURA}

1) Adams, A. M., Gathercole, S. E. (2000). Limitations in working memory: Implications for language development. International Journal of Language and Communication Disorders.

2) Anić, V., Rončević, D. B., Goldstein, I., Goldstein, S., Jojić, L., Matasović, R., Pranjković, I. (2002). Hrvatski enciklopedijski rječnik. Novi liber.

3) Archibald, L. M., Gathercole, S. E. (2007). Nonword repetition in specific language impairment: More than a phonological short-term memory deficit. Psychonomic bulletin and review, 14(5), 919-924.

4) Berko, J. (1958). 'The child's learning of English morphology. Word, 14(2-3), 150-177.

5) Bilonić Milošević, S. (2012). Razlike između djece s neurološkim odstupanjima i djece bez neuroloških odstupanja na zadatcima jezičnog znanja. Edukacijskorehabilitacijski fakultet (neobjavljen magistarski rad)

6) Bishop, D. V., Snowling, M. J. (2004). Developmental dyslexia and specific language impairment: Same or different?. Psychological bulletin, 130(6), 858.

7) Chialant, D., Caramazza, A. (1995). Where is morphology and how is it processed? The case of written word recognition. Morphological aspects of language processing, 55-76.

8) Chiat, S. (2001). Mapping theories of developmental language impairment: Premises, predictions and evidence. Language and cognitive processes, 16(2-3), 113-142.

9) Chiat, S., Roy, P. (2007). The Preschool Repetition Test: An evaluation of performance in typically developing and clinically referred children. Journal of Speech, Language, and Hearing Research, 50(2), 429-443.
10) Coady, J. A., Evans, J. L. (2008). Uses and interpretations of non-word repetition tasks in children with and without specific language impairments (SLI). International Journal of Language and Communication Disorders, 43(1), 1-40.

11) Coltheart, M. (2005). Modeling Reading: The DualRoute Approach.

12) Coltheart, M. (2006). Dual route and connectionist models of reading: An overview. London Review of Education, 4(1), 5-17.

13) Conti-Ramsden, G., Botting, N., Faragher, B. (2001). Psycholinguistic markers for specific language impairment (SLI). Journal of Child Psychology and Psychiatry, 42(6), 741-748. 14) Dollaghan, C., Campbell, T. F. (1998). Nonword repetition and child language impairment. Journal of Speech, Language, and Hearing Research, 41(5), 1136-1146.

15) Estes, K. G., Evans, J. L., Else-Quest, N. M. (2007). Differences in the nonword repetition performance of children with and without specific language impairment: A meta-analysis. Journal of Speech, Language, and Hearing Research, 50(1), 177-195.

16) Friederici, A. D. (2002). Towards a neural basis of auditory sentence processing. Trends in cognitive sciences, 6(2), 78-84.

17) Frisch, S. A., Large, N. R., Pisoni, D. B. (2000). Perception of wordlikeness: Effects of segment probability and length on the processing of nonwords. Journal of memory and language, 42(4), 481-496.

18) Gathercole, S. E., Baddeley, A. D. (1990). Phonological memory deficits in language disordered children: Is there a causal connection?. Journal of memory and language, 29(3), 336360 .

19) Gathercole, S. E., Baddeley, A. D. (1993). Phonological working memory: A critical building block for reading development and vocabulary acquisition?. European Journal of Psychology of Education, 8(3), 259-272.

20) Gathercole, S. E., Frankish, C. R., Pickering, S. J., Peaker, S. (1999). Phonotactic influences on short-term memory. Journal of Experimental Psychology: Learning, Memory, and Cognition, 25(1), 84.

21) Gibbs, P., \& Van Orden, G. C. (1998). Pathway selection's utility for control of word recognition. Journal of Experimental Psychology: Human Perception and Performance, 24(4), 1162.

22) Hagoort, P. (2005). On Broca, brain, and binding: a new framework. Trends in cognitive sciences, 9(9), 416-423.

23) Ivšac Pavliša, J., Lenček, M. (2011) Fonološke vještine i fonološko pamćenje: neke razlike između djece urednog jezičnog razvoja, djece s perinatalnim oštećenjem mozga $\mathrm{i}$ djece s posebnim jezičnim teškoćama kao temeljni prediktor čitanja. Hrvatska revija za rehabilitacijska istraživanja 47(1). $1-16$.

24) Kavitskaya, D., Babyonyshev, M., Walls, T., Grigorenko, E. (2011). Investigating the effects of syllable complexity in Russian-speaking children with SLI. Journal of child language, 38(05), 979-998.

25) Ljubešić, M. (1997). Jezične teškoće školske djece. NIP Školske novine.

26) Ljubešić, N., Klubička F. (2014): Proceedings of the 9th Web as Corpus Workshop (WaC-9). Association for Computational Linguistics.

27) McDonald, J. L. (1997). Language acquisition: The acquisition of linguistic structure in normal and special 
populations. Annual Review of Psychology, 48(1), 215-241. 28) Metsala, J. L. (1999). Young children's phonological awareness and nonword repetition as a function of vocabulary development. Journal of Educational Psychology, 91(1), 3.

29) Montgomery, J. W. (2002). Understanding the Language Difficulties of Children With Specific Language Impairments. Does Verbal Working Memory Matter? American Journal of Speech-Language Pathology, 11(1), 77-91.

30) Munson, B., Kurtz, B. A., Windsor, J. (2005). The influence of vocabulary size, phonotactic probability, and wordlikeness on nonword repetitions of children with and without specific language impairment. Journal of Speech, Language, and Hearing Research, 48(5), 1033-1047.

31) Nijland, L., Maassen, B., Meulen, S. V. D., Gabreëls, F., Kraaimaat, F. W., \& Schreuder, R. (2002). Coarticulation patterns in children with developmental apraxia of speech. Clinical Linguistics and Phonetics, 16(6), 461-483.

32) Palmović, M., Kuvač, J., Kovačević, M. (2007.) Istraživanja posebnih jezičnih teškoća metodom kognitivnih evociranih potencijala (KEP). Revija za rebabilitacijska istraživanja, 43(1), 63-73.

33) Ramus, F., Marshall, C. R., Rosen, S., van der Lely, H. K. (2013). Phonological deficits in specific language impairment and developmental dyslexia: towards a multidimensional model. Brain, 136(2), 630-645.

34) Rispens, J., Baker, A., Duinmeijer, I. (2015). Word Recognition and Nonword Repetition in Children With Language Disorders: The Effects of Neighborhood Density, Lexical Frequency, and Phonotactic Probability. Journal of Speech, Language, and Hearing Research, 58(1), 78-92.

35) Roy, P., Chiat, S. (2004). A Prosodically Controlled Word and Nonword Repetition Task for 2-to 4-YearOldsEvidence From Typically Developing Children. Journal of Speech, Language, and Hearing Research, 47(1), 223-234.

36) Stokes, S. F., Wong, A. M., Fletcher, P., Leonard, L. B. (2006). Nonword repetition and sentence repetition as clinical markers of specific language impairment: The case of Cantonese. Journal of Speech, Language, and Hearing Research, 49(2), 219-236.

37) Zaretsky, E., Kuvač Kraljević, J., Core, C., Lenček, M. (2009.) Literacy predictors and early reading and spelling skills as a factor of ortography: Cross-linguistic evidence. Written Language and Literacy, 12(1), 52-81.

38) Weismer, S. E., Tomblin, J. B., Zhang, X., Buckwalter, P., Chynoweth, J. G., Jones, M. (2000). Nonword repetition performance in school-age children with and without language impairment. Journal of Speech, Language, and Hearing Research, 43(4), 865-878.

39) Wild, N., Fleck, C. (2013). Neunormierung des MottierTests für 5-bis 17-jährige Kinder mit Deutsch als Erst-oder als Zweitsprache. Praxis Sprache, 3, 152-157.

\section{Zahvala}

Ovo ispitivanje provedeno je u sklopu projekta Interdisciplinarni pristup razvoju jezično-kognitivnog modela disleksije kod odraslih (HR.3.2.01-0247), u okviru Strukturni i investicijski fondovi Operativnog programa Razvoj ljudskih potencijala - dodijeljenom Odsjeku za logopediju Edukacijsko-rehabilitacijskog fakulteta Sveučilišta u Zagrebu.

Zahvaljujemo kolegi Nikoli Bakariću, doktorandu Filozofskog fakulteta, i kolegi Vanji Štefancu, doktorandu Interdisciplinarnog studija Jezile $i$ kognitivna znanost, na pomoći u dijelu istraživanja kojim su dobiveni podaci iz Hrvatskog web korpusa. 